\title{
DIFFERENTIAL BEHAVIOR OF YOUNG EUCALYPTUS CLONES IN RESPONSE TO NITROGEN SUPPLY
}

\author{
Eric Victor de Oliveira Ferreira ${ }^{(1) *}$, Roberto Ferreira Novais ${ }^{(2)}$, Greice Leal Pereira ${ }^{(3)}$, Nairam
}

Félix de Barros $^{(4)}$ and Ivo Ribeiro da Silva ${ }^{(4)}$

\footnotetext{
(1) Universidade de São Paulo, Escola Superior de Agricultura "Luiz de Queiroz", Departamento de Ciências Florestais, Piracicaba, São Paulo, Brasil.

(2) Universidade Federal de Viçosa, Instituto de Ciências Agrárias, Campus Rio Paranaíba, Rio Paranaíba, Minas Gerais, Brasil.

(3) Universidade de São Paulo, Escola Superior de Agricultura "Luiz de Queiroz", Departamento de Ciência do Solo, Programa de Pós-graduação em Solos e Nutrição de Plantas, Piracicaba, São Paulo, Brasil.

(4) Universidade Federal de Viçosa, Departamento de Solos, Viçosa, Minas Gerais, Brasil.

* Corresponding author.

E-mail: ericsolos@yahoo.com.br
}

\begin{abstract}
Eucalyptus requires large amounts of nitrogen $(\mathrm{N})$; however, it responds in diverse manners to the application of this nutrient. The aim of this study was to evaluate the differential performance in growth, mineral nutrition, and gas exchanges of $\mathrm{N}$-fertilized Eucalyptus clones. The treatments consisted of two Eucalyptus clones (VM-01 and I-144) and six $\mathrm{N}$ application rates $\left(0,0.74,2.93,4.39,5.85\right.$, and $\left.8 \mathrm{mmol} \mathrm{L}^{-1} \mathrm{NH}_{4} \mathrm{NO}_{3}\right)$ arranged in a randomized complete block design with five replications. VM-01 had greater plant height and greater height/collar diameter ratio, as well as higher leaf concentrations of all macronutrients and of $\mathrm{Cu}, \mathrm{Fe}, \mathrm{Mo}$, and $\mathrm{Zn}$. In terms of total and root dry matter production, root/shoot ratio, and collar diameter, as well as stomatal conductance and transpiration, I-144 performed better. The performance of the clones was clearly differentiated, and the growth of I-144, despite lower leaf $\mathrm{N}$ concentration, was in general better than VM-01.
\end{abstract}

Keywords: gas exchange, growth, nutrient solution, nutritional efficiency. 


\title{
RESUMO: COMPORTAMENTO DIFERENCIADO DE CLONES JOVENS DE EUCALIPTO EM RESPOSTA AO SUPRIMENTO DE NITROGÊNIO
}

\begin{abstract}
O nitrogênio é requerido em grandes quantidades pelo eucalipto; entretanto, as repostas à aplicação desse nutriente são divergentes. O objetivo deste trabalho foi avaliar o comportamento diferenciado em crescimento, na nutrição mineral e nas trocas gasosas de clones de eucalipto supridos com $N$. Os tratamentos consistiram de dois clones de eucalipto (VM-01 e I-144) e seis doses de N (0; 0,74; 2,93; 4,39; 5,85; e $8 \mathrm{mmol} \mathrm{L}^{-1}$ de $\mathrm{NH}_{4} \mathrm{NO}_{3}$ ), dispostos em delineamento de blocos casualizados com cinco repetições. O clone VM-01 foi superior em altura e altura/diâmetro do colo e teve maiores concentrações foliares de todos os macronutrientes e de $\mathrm{Cu}$, Fe, Mo e Zn. Em termos de produção de matéria seca da raiz e total, raiz/parte aérea e diâmetro do colo, bem como em condutância estomática e transpiração, o clone I-144 teve melhor performance. O desempenho dos clones foi claramente diferenciado, e o crescimento do I-144, independetemente de menor concentração foliar de N, foi em geral melhor que do VM-01.
\end{abstract}

Palavras-chave: crescimento, eficiência nutricional, solução nutritiva, trocas gasosas.

\section{INTRODUCTION}

Brazil is one of the largest producers of Eucalyptus pulp and paper worldwide (SBS, 2006). Eucalyptus is the most widely planted forest species of the country, grown on nearly 4.9 million hectares in 2011 (Abraf, 2012). Most of these Eucalyptus forests are planted on low fertility soils, frequently resulting in growth limitations due to insufficient nutrient supply (Barros and Novais, 1996; Leite et al., 2011), and nutritional deficiencies have been documented (Silveira et al., 1995). Consequently, Brazil is the country in which Eucalyptus responds best to mineral fertilization (Pinto, 2009), and there is the need for high fertilizer applications to increase yields (Barros et al., 2004).

Lack of $\mathrm{N}$ is one of the factors that most limits plant growth and development (Majerowicz et al., 2000), and it is required in large amounts (Marschner, 2012). However, for Eucalyptus, the effects of its application on dry matter production are sometimes positive (Smethurst et al., 2004; Jesus et al., 2012) but, in other cases, ineffective (Stape and Benedetti, 1997; Garategui, 2002; Pulito, 2009). Gonçalves et al. (2000) reported that the intensity of Eucalyptus response to $\mathrm{N}$ fertilization is low. Furthermore, some studies have reported nutritional differences among Eucalyptus species (Furtini Neto et al., 1996; Santana et al., 2002), e.g., in terms of response to $\mathrm{N}$ fertilization - as indicated by Pinto et al. (2011), who also mentioned the importance of information on nutrient demand and the efficiency of clones in converting the nutrients taken up into biomass. The intra- and interspecific variability in Eucalyptus species is wide, especially in characteristics such as biomass production and growth rate (Chaperon, 1987). Changes in the root/ shoot ratio in response to nutrient availability may be related to the maximization of uptake and use of available nutrients and carbohydrates for plant growth (Cruz et al., 1993; Majerowicz and Kerbauy, 2002). The understanding of the mechanisms that control the partitioning of carbohydrates and nutrients between different plant parts is still limited (Marschner et al., 1996).

Nitrogen deficiency rapidly inhibits plant growth and, in most species, older leaves become chlorotic, with necrosis and subsequent leaf drop in the case of severe deficiency (Marschner, 2012). The main effect of low $\mathrm{N}$ availability is a decrease in the rate of photosynthesis (Hay and Porter, 2006), with reduction in chlorophyll and RuBisCO leaf concentrations (Bungard et al., 1997). $\mathrm{N}$ is an essential component of proteins, chlorophyll, and thylakoids (Raven et al., 1986) and the distribution of leaf $\mathrm{N}$ throughout the canopy maximizes the whole-canopy carbon gain, because of differences in irradiance (Field, 1983). The formation of new shoot tissue raises the demand for $\mathrm{N}$ for protein synthesis (Majerowicz and Kerbauy, 2002). The $\mathrm{N}$ taken up is incorporated into the plant as amino acid and, with increasing $\mathrm{N}$ accumulation the synthesized proteins promote leaf growth, increasing the photosynthetic surface area (Dechen and Nachtigall, 2007). Thus, dry matter accumulation depends on the amount of $\mathrm{N}$ that the plant can take up and the leaf area built up per unit of absorbed N (Hay and Porter, 2006); leaf area index (LAI) and absorbed $\mathrm{N}$ are closely correlated (Hirel et al., 2007). There is, consequently, a close relationship among $\mathrm{N}$ supply, leaf $\mathrm{N}$ distribution, and photosynthesis (Gastal and Lemaire, 2002).

Thus, the Eucalyptus clones are expected to have different growth responses due to differences in the nutritional demand and gas exchanges under different $\mathrm{N}$ application rates. Therefore, the aim of this study was to evaluate the differential behavior of young Eucalyptus clones in terms of growth, mineral nutrition, and gas exchanges under the application of different $\mathrm{N}$ rates in the nutrient solution. 


\section{MATERIAL AND METHODS}

The experiment was carried out in a greenhouse of the Soil Science Department of the Unversidade Federal de Viçosa (Federal University of Viçosa), in Viçosa, MG, Brazil (20 $45^{\prime} 14^{\prime \prime} \mathrm{S}, 42^{\circ} 52^{\prime} 53^{\prime \prime} \mathrm{W}$ ), from July to September 2011. Air temperature in the greenhouse was recorded daily and reached minimum and maximum values of 7.9 and $33.9{ }^{\circ} \mathrm{C}$, respectively. The first 30 days represented the plant acclimatization stage in the nutrient solution, and the other 60 days, the period of plant treatments. Clark's nutrient solution (Clark, 1975) was modified to an $\mathrm{NH}_{4}^{+}-\mathrm{N}^{-} \mathrm{NO}_{3}^{-}-\mathrm{N}$ ratio of 1 (Locatelli et al., 1984), the $\mathrm{P}$ concentration was doubled (Caldeira et al., 1994), and the $\mathrm{N}$ rate was varied (with $2.93 \mathrm{mmol} \mathrm{L}^{-1}$ of $\mathrm{NH}_{4} \mathrm{NO}_{3}$ as a reference), according to the treatments (Ferreira, 2013).

Every seven days, the concentration of the nutrient solution in a collective plastic tray $(11 \mathrm{~L})$ in the plant acclimatization stage was gradually increased (25, 50,75 , and $100 \%$ of the original concentration of the modified Clark's solution). After acclimatization, two homogeneous plants were selected (according to height and vigor) and transferred to a plastic pot $(6 \mathrm{~L})$, representing an experimental unit. The nutrient solution was continuously aerated and exchanged weekly, using deionized water, and the $\mathrm{pH}$ adjusted daily to $5.5 \pm 0.05$ (Locatelli et al., 1984) by adding $\mathrm{H}_{2} \mathrm{SO}_{4}$ or $\mathrm{NaOH}$ solution $\left(0.1 \mathrm{~mol} \mathrm{~L}^{-1}\right)$.

The treatments consisted of two Eucalyptus clones (VM-01 and I-144) and six N application rates (0, 0.74, 2.93, 4.39, 5.85, and $8 \mathrm{mmol} \mathrm{L}^{-1} \mathrm{NH}_{4} \mathrm{NO}_{3}$ ) arranged in a $2 \times 6$ factorial randomized complete block design with five replications. The clone VM-01 is a hybrid (Eucalyptus urophylla $\times$ E. camaldulenses) and was chosen because it is considered as more $\mathrm{N}$-demanding. In contrast, clone I-144 is an E. urophylla and is considered less $\mathrm{N}$-demanding. The clones were young plants derived from approximately 50-day-old tube seedlings at the beginning of the trial, provided by the forestry companies Vallourec and Mannesmann Tubes (VM-01) and Arcelor Mittal (I-144).

At the end of the experimental period, plant height, collar diameter and root length were measured, and the height/collar diameter ratio was calculated. The height and root length were measured with a graduated ruler (in $\mathrm{cm}$ ), and the collar diameter of the plants with a digital caliper rule (in $\mathrm{mm}$ ). For gas exchanges, eight readings were taken in $1 \mathrm{~min}$ (mean value was used) between 7 and 11 a.m. in the youngest fully expanded leaf of each plant using an infrared gas analyzer (IRGA, Li-6400xt, Licor) at environment temperature and humidity and constant radiation $\left(1,000 \mathrm{mmol} \mathrm{m}^{-2} \mathrm{~s}^{-1}\right)$, as described by Nunes (2010). The photosynthesis $(A)$, stomatal conductance $\left(g_{\mathrm{s}}\right)$, internal $\mathrm{CO}_{2}$ concentration $\left(C_{\mathrm{i}}\right)$, external $\mathrm{CO}_{2}$ concentration $\left(C_{\mathrm{a}}\right)$, leaf ratio $\left(C_{\mathrm{i}} / C_{\mathrm{a}}\right)$, and transpiration $(E)$ were evaluated. The plants were subsequently harvested; their leaves, stems, branches, and roots were separated, washed with deionized water, and then oven-dried $\left(60^{\circ} \mathrm{C}\right)$ to constant weight to obtain the dry matter of the different plant tissues. The sum of dry matter of leaves, stem, and branches represents shoot dry matter, and total dry matter is the sum of root and shoot dry matter.

All leaves were ground (Willey mill) and taken to the laboratory to evaluate the concentration of macro- $(\mathrm{N}$, $\mathrm{P}, \mathrm{K}, \mathrm{Ca}, \mathrm{Mg}$, and $\mathrm{S})$ and micronutrients $(\mathrm{B}, \mathrm{Cu}, \mathrm{Fe}$, $\mathrm{Mn}, \mathrm{Mo}$, and $\mathrm{Zn}$ ). After mineralization of the material by sulfuric acid and heating, leaf $\mathrm{N}$ was determined by the Kjeldahl method (Bremner, 1996). To assess the concentration of all other nutrients, the samples were mineralized by calcination in a muffle furnace (gradually increasing the temperature to $500{ }^{\circ} \mathrm{C}$, maintained for $3 \mathrm{~h})$ with subsequent extraction in $\mathrm{HCl}\left(0.01 \mathrm{~mol} \mathrm{~L}^{-1}\right)$ and determination according to Malavolta et al. (1997) by inductively coupled plasma-optical emission spectrophotometry (ICP-OES).

All data were subjected to analysis of variance (F test) to test the effects of clones, $\mathrm{N}$ rates, and their interactions on measured variables by the general linear model procedure (PROC GLM) of the SAS statistical package (SAS, 2004). Quadratic and square root regression models were fitted to describe these relations, and the significant model $(\mathrm{p}<0.05)$ with the highest determination coefficient $\left(\mathrm{R}^{2}\right)$ was selected.

\section{RESULTS AND DISCUSSION}

The application of N increased shoot, root, and total dry matter, inducing higher production in clone I-144 (Figures 1a, 1b and 1d). Pinto et al. (2011) observed that clone I-144 has high efficiency in $\mathrm{N}$ uptake and utilization, whereas VM-01 has high uptake efficiency but low utilization efficiency. The clones VM-01 and I-144 reached maximum values of total dry matter of 25.4 and $30.0 \mathrm{~g} /$ plant, respectively, at the rate of $2.93 \mathrm{mmol} \mathrm{L}^{-1} \mathrm{~N}$, i.e., the rate recommended in Clark's nutrient solution (Clark, 1975). The effects of $\mathrm{N}$ application on Eucalyptus growth are positive in some cases (young plants, Jesus et al., 2012) and ineffective in others (adult plants, Pulito, 2009). According to Barros et al. (1990), N accelerates the initial growth rate of the forest; however, differences between treatments are no longer significant after 30 months, as noted by Pulito (2009).

Root/shoot dry matter decreased with increasing $\mathrm{N}$ for the two clones studied (Figure 1c). As expected, the root/shoot ratio was highest in plants grown in the $\mathrm{N}$-free solution, due to the relatively lower production of shoot dry matter under this condition (Figure 1a). Additionally, in the absence of any limiting factor, root growth tends to increase, which, however, does not necessarily result in higher dry matter production for this organ (Figure 1b). Thus, under $\mathrm{N}$ deficiency, root system growth 
increases, in a relative manner (Marschner, 2012), shoot growth reduces, and the root/shoot ratio may change (Améziane et al., 1995) through altered carbohydrate allocation. The increase in root/shoot ratio under $\mathrm{N}$ deficiency has been correlated with a shift in endogenous phytohormone levels, with an increase in abscisic acid and a decrease in cytokinins (Marschner, 1995).

The Eucalyptus clones differed in regard to plant height, collar diameter, and height/collar diameter

(a)

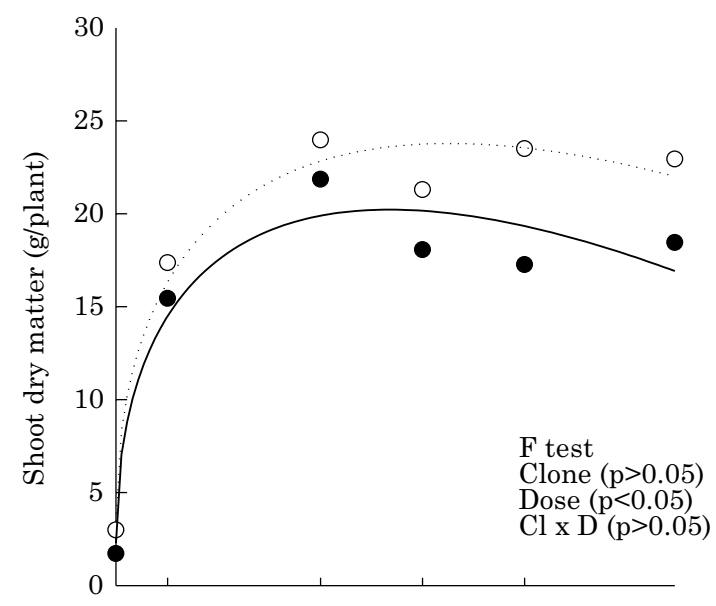

$\begin{array}{ll}-\hat{\mathrm{y}}=2.28-4.58^{*} \mathrm{x}+18.13^{*} \mathrm{x}^{0.5} & \mathrm{R}^{2}=0.93 \\ \ldots \ldots \hat{\mathrm{y}}=3.48-4.26^{*} \mathrm{x}+18.60^{* *} \mathrm{x}^{0.5} & \mathrm{R}^{2}=0.97\end{array}$

(c)

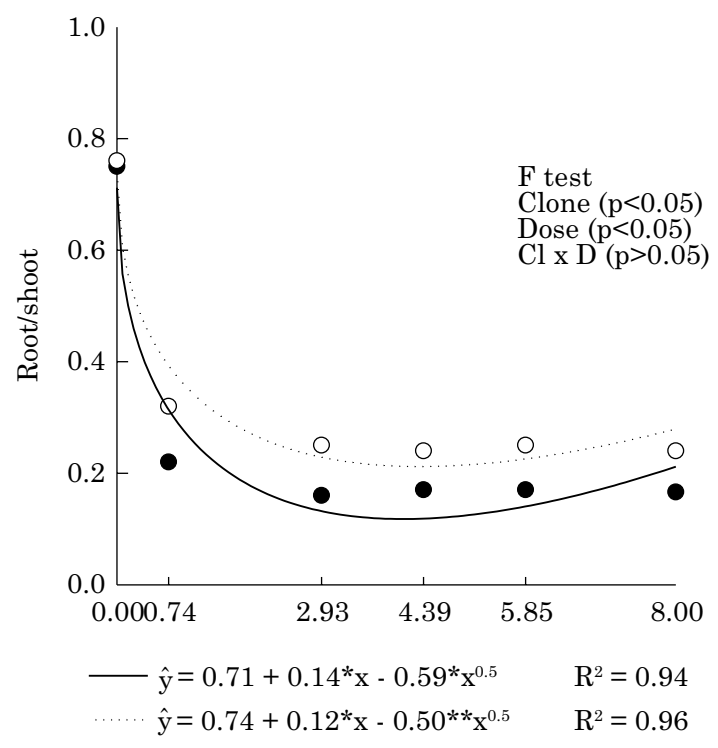

ratio, but not in root length ( $>>0.05$ ) (Figure 2 ). With increasing $\mathrm{N}$ application rates, the clones increased in plant height (Figure 2a) and collar diameter (Figure 2b), while there was no difference $(p>0.05)$ in the height/collar diameter ratio (Figure 2c). The $\mathrm{N}$ application rates led to a reduction in root length for VM-01, but had no effect on this variable for I-144 (Figure 2d). The plant height and the height/collar diameter ratio of clone VM-01 were greater, while the collar diameter of I-144 was

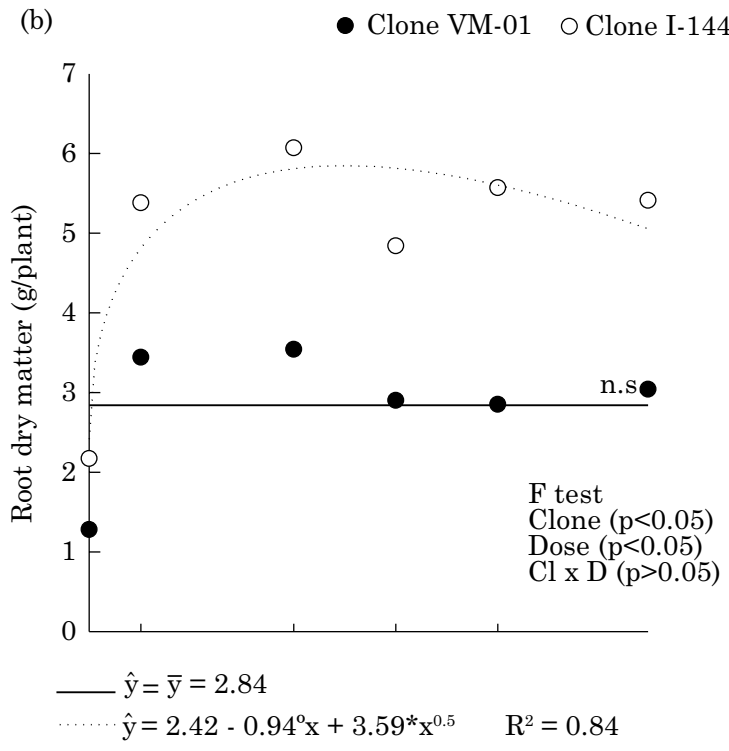

(d)

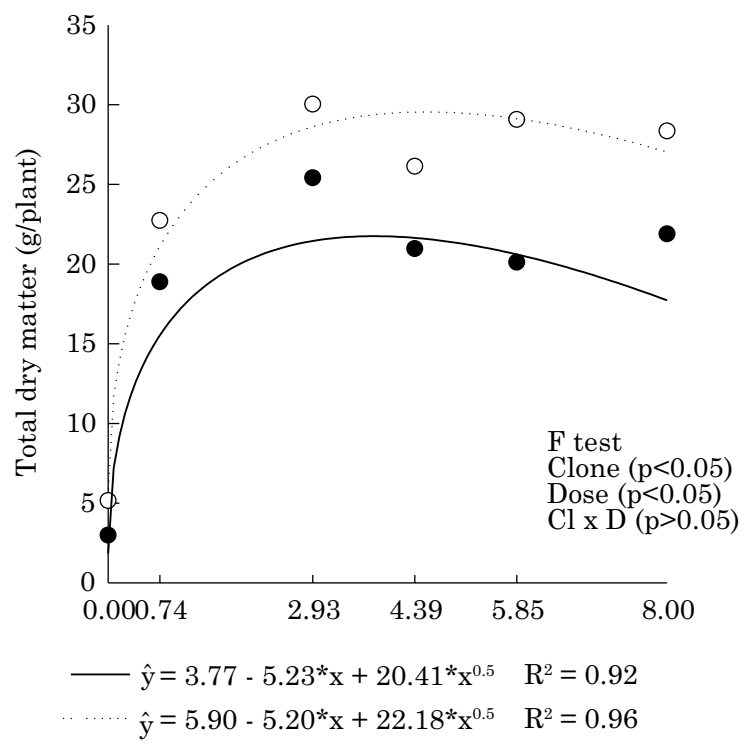

$\mathrm{N}$ application rate $\left(\mathrm{mmol} \mathrm{L}^{-1}\right.$ of $\left.\mathrm{NH}_{4} \mathrm{NO}_{3}\right)$

Figure 1. Shoot (a) and root (b) dry matter, root/shoot (c), and total dry matter (d) of young eucalyptus clones under $\mathrm{N}$ application rates in nutrient solution. ${ }^{\mathrm{ns}},{ }^{\circ}, *$, and $* *$ represent not significant, and significant at 10,5 , and $1 \%$ by the $\mathrm{F}$ test $(\mathrm{p}<0.05)$, respectively. $\mathrm{Cl}$ (clone) and $\mathrm{D}$ (application rate). 
greater. This differentiated plant growth of different genotypes grown under the same conditions may indicate differences in the internal factors related to nutritional efficiency (Martinez et al., 1993).

In a study of Wadt et al. (1999) on variations in the nutritional status of Eucalyptus under the influence of different genotypes and tree ages, $\mathrm{N}$ demand was highest at the beginning of the crop cycle. Thus, the $\mathrm{N}$ nutrition of these clones in the early growth stages should be further investigated,

(a)

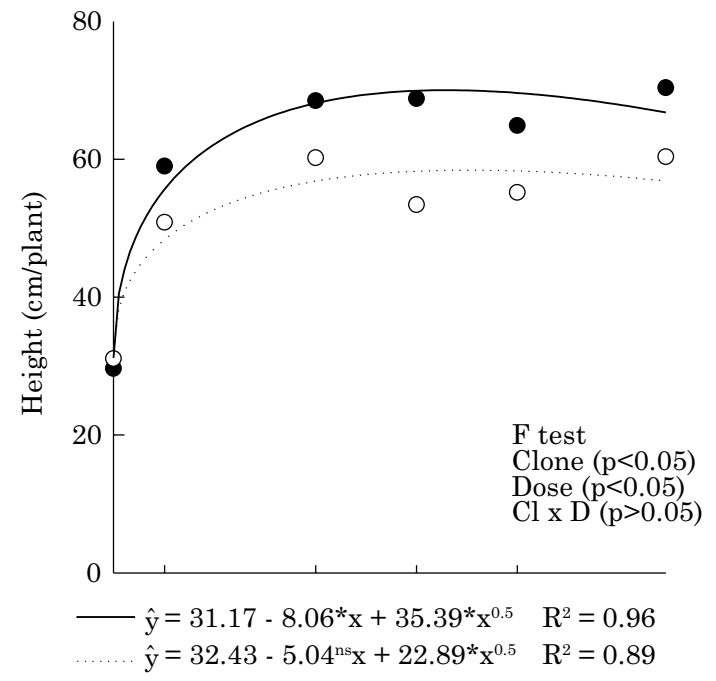

(c)

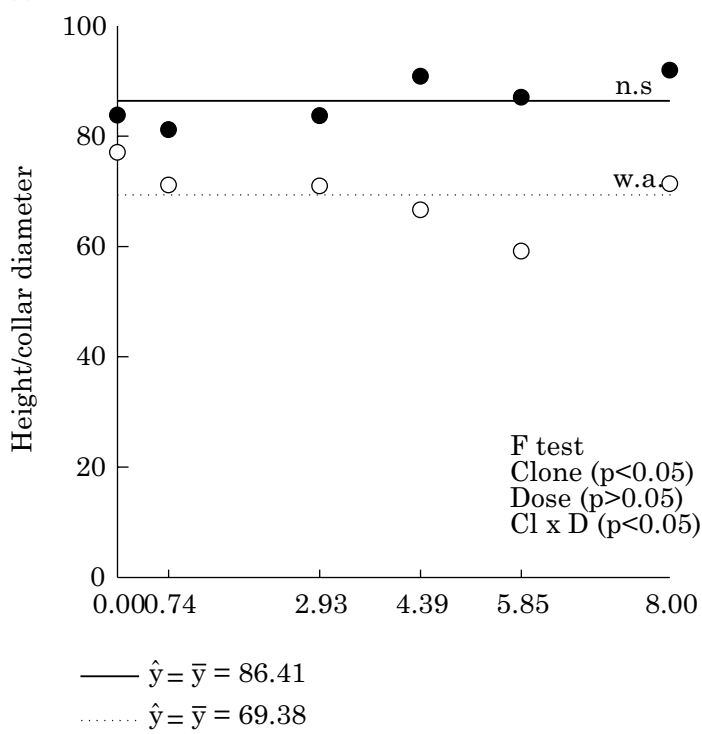

especially that of clone VM-01, which, according to Pinto et al. (2011), has lower N use efficiency.

With regard to gas exchange, there was no difference $(p>0.05)$ between the clones in photosynthesis $(A)$ (Figure $3 \mathrm{a}$ ) and the $C_{\mathrm{i}} / C_{\mathrm{a}}$ (Figure 3c). The values of $A$ clearly increased with increasing $\mathrm{N}$ in the solution, while the $C_{\mathrm{i}} / C_{\mathrm{a}}$ was little affected by $\mathrm{N}$ application rates. In contrast, the stomatal conductance $\left(g_{s}\right)$ (Figure $3 b$ ) and transpiration $(E)$ (Figure 3d) of clone VM-01 were

(b)

- Clone VM-01 O Clone I-144

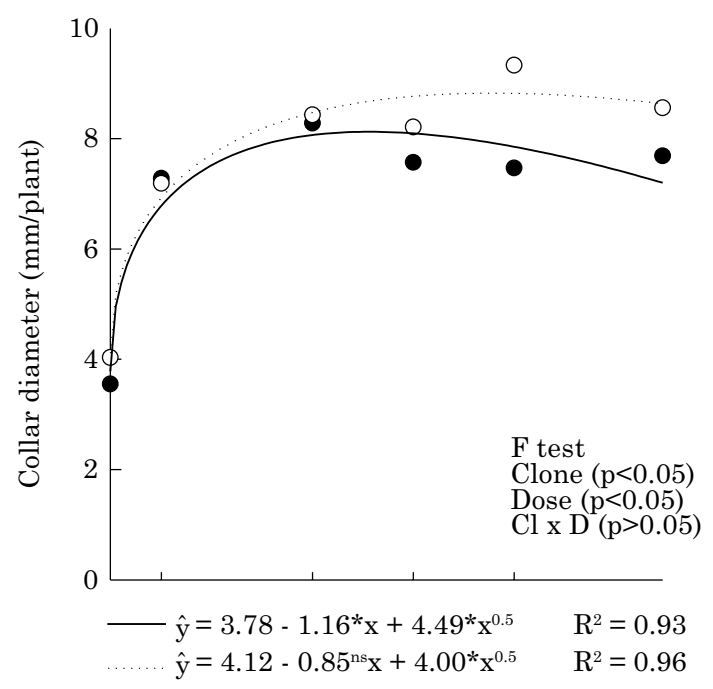

(d)

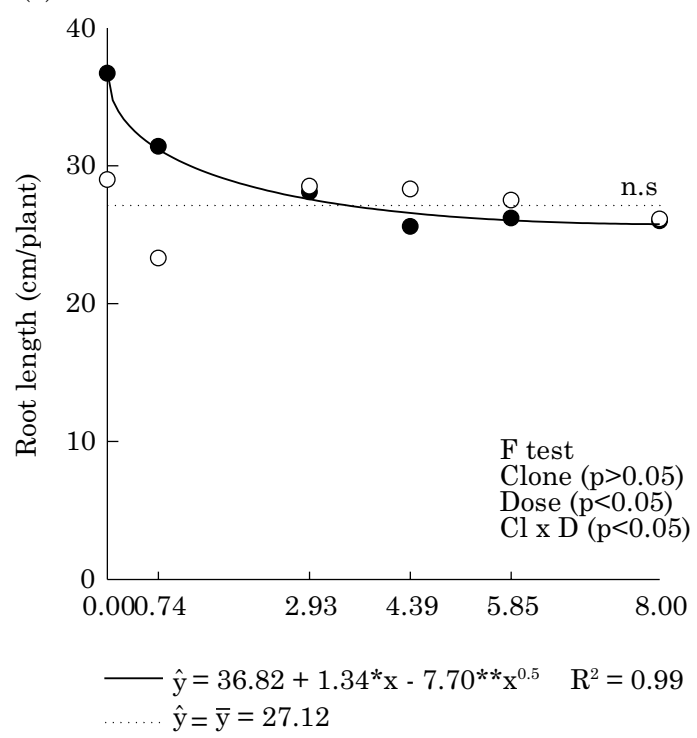

$\mathrm{N}$ application rate $\left(\mathrm{mmol} \mathrm{L}-1\right.$ of $\left.\mathrm{NH}_{4} \mathrm{NO}_{3}\right)$

Figure 2. Height (a), collar diameter (b), height/collar diameter ratio (c), and root length of young eucalyptus clones under $\mathrm{N}$ application rates in nutrient solution. ${ }^{\mathrm{ns}}$, wa, ${ }^{*}$, and ** represent not significant, without adjustment, and significant at 5 and $1 \%$ by the $F$ test $(p<0.05)$, respectively. $\mathrm{Cl}$ (clone) and D (application rate). 
lowest. The $g_{s}$ and $E$ values of this clone were increased by increasing $\mathrm{N}$ application rates until they reached their peaks $\left(0.41 \mu \mathrm{mol} \mathrm{m}{ }^{-2} \mathrm{~s}^{-1} \mathrm{H}_{2} \mathrm{O}\right.$ and $5.4 \mathrm{mmol} \mathrm{m}^{-2} \mathrm{~s}^{-1} \mathrm{H}_{2} \mathrm{O}$, respectively). For clone $\mathrm{I}-144$, although the $\mathrm{N}$ application rates influenced these same variables, there was no adjustment (without adjustment - w.a.) to the tested regression models for $g_{\mathrm{s}}$, and the $\mathrm{N}$ application rates were not significant (n.s.) for $E$. In 4-year-old $E$. globulus trees, $\mathrm{N}$ fertilization (plus $\mathrm{P}, \mathrm{K}$, and $\mathrm{S}$ ) also stimulated a $20 \%$ increase in height, an increase in leaf $\mathrm{N}$ concentration and $g_{\mathrm{s}}$, and an increase in the $C_{\mathrm{i}} / C_{\mathrm{a}}$ (Turnbull et al., 2007).

The positive response of $A$ to $\mathrm{N}$ application (Figure 3a) was expected, since this nutrient is positively correlated with photosynthesis (Niinemmets et al., 2006). Nitrogen is part of enzymes that participate in photosynthetic processes, especially of RuBisCO (Onoda et al., 2004), as well as being present in the chlorophyll molecule (Dechen and Nachtigall, 2007). In most species, $\mathrm{N}$ deficiency induces a significant decrease in $A$ and $g_{s}$ (Hunt et al., 1985). However, the response of stomata to $\mathrm{N}$ deficiency can vary from increase (Ciompi et al., 1996) to decrease (Lima et al., 2000).

Although the $A$ values of the clones were similar (Figure $3 \mathrm{a}$ ), the $g_{s}$ values (Figure $3 \mathrm{~b}$ ) and total dry matter of VM-01 were lower (Figure 1d) than I-144. In general, the increase in $g_{s}$ (Figure $3 \mathrm{~b}$ ) due to $\mathrm{N}$ application induced an increase in $E$ (Figure $3 d$ ) and $A$ (Figure 3a), although not in the $C_{\mathrm{i}} / C_{\mathrm{a}}$ (Figure $3 \mathrm{c}$ ), which resulted in a gain in total dry matter (Figure 1d). Müller et al. (2012) verified that the reduction in $g_{s}$ is related to the reduction in $E$ and $A$ in Eucalyptus clones grown with B supply in the nutrient solution. They reported values of around $20 \mu \mathrm{mol} \mathrm{m}^{-2} \mathrm{~s}^{-1} \mathrm{CO}_{2}$ for $A$ and between 0.4 and $0.5 \mu \mathrm{mol} \mathrm{m} \mathrm{m}^{-2} \mathrm{~s}^{-1} \mathrm{H}_{2} \mathrm{O}$ for $g_{s}$ in plants of the control treatment. In another experiment with Eucalyptus, also with the addition of $\mathrm{B}$ in the nutrient solution, higher $g_{s}$ values were also associated with higher $E$, indicating that conditions that promote greater dry matter production also favor greater transpiration flow (Nunes, 2010). Changes in $g_{s}$ have been described as being involved with control of water loss and $\mathrm{CO}_{2}$ uptake $\left(C_{\mathrm{i}}\right)$ to maintain the photosynthetic rate (Taiz and Zeiger, 2004).

The decrease in $g_{s}$ can restrict $\mathrm{CO}_{2}$ availability, with a consequent decrease in $\mathrm{CO}_{2}$ concentrations in the substomatal cavities and intercellular spaces (Daley et al., 1989). A limited $g_{s}$ normally results in a reduction in photosynthesis (Reddy et al., 2004). However, a stable leaf-internal $\mathrm{CO}_{2}$ concentration was observed, despite the $g_{s}$ limitation (Warren et al., 2007). The minor variations in the $C_{\mathrm{i}} / C_{\mathrm{a}}$ (Figure 3c) observed in this study did not negatively affect $A$ (Figure 3a) and total dry matter (Figure 1d), perhaps because of the low magnitude of these alterations, avoiding a significant effect on the other variables evaluated, apart from the increase in $g_{s}$ (Figure $3 b$ ). Mattiello et al. (2009) also observed that the $C_{\mathrm{i}} / C_{\mathrm{a}}$ remained practically unaltered (between $0.7-0.8$ ) in eight Eucalyptus clones grown in Clark's solution with $\mathrm{B}$ addition, emphasizing that the substrate $\left(\mathrm{CO}_{2}\right)$ was not limiting for $A$.

The clones differed $(\mathrm{p}<0.05)$ for all leaf macronutrients evaluated, and clone VM-01 showed the highest values (Figure 4). Differences in nutritional efficiency between Eucalyptus clones have also been observed by other authors (Neves, 2000; Lima et al., 2005; Pinto et al., 2011) and, according to Furtini Neto (1994), this fact suggests the possibility of selection and adaptation of Eucalyptus genotypes to different soil conditions, specifically those with low natural fertility (Pinto et al., 2011).

The application of $\mathrm{N}$ resulted in an increase in the leaf $\mathrm{N}$ concentration of the Eucalyptus clones tested, fitting the square root model (Figure 4a). The higher concentrations of leaf $\mathrm{N}$ in clone VM-01 indicate its greater demand for this nutrient. In comparison to the $\mathrm{N}$-free treatment (application rate 0), a small application of this nutrient $\left(0.74 \mathrm{mmol} \mathrm{L}^{-1}\right.$ of $\left.\mathrm{NH}_{4} \mathrm{NO}_{3}\right)$ was enough to raise the leaf $\mathrm{N}$ concentration of VM-01 by approximately 2.5 times, and by three times in leaves of I-144. Furlani (2004) reported that plants grown at low $\mathrm{N}$ concentrations have a light green color, characterized by generalized chlorosis, especially in older leaves, because $\mathrm{N}$ is a mobile element within plants. In our experiment, this symptom was observed in plants grown at application rates of 0 and $0.74 \mathrm{mmol} \mathrm{L}^{-1} \mathrm{NH}_{4} \mathrm{NO}_{3}$ as of the second week of treatment. The increase in leaf $\mathrm{N}$ concentration (Figure 4a) was accompanied not only by an increase in $A$ (Figure $3 a$ ), but also in total dry matter for both clones (Figure 1d), after N application in the solution. However, as clone VM-01 had higher leaf $\mathrm{N}$ concentration but lower total dry matter production, we concluded that its $\mathrm{N}$ use efficiency is lower, as also stated by Pinto et al. (2011). Nitrogen deficiency reduces chlorophyll synthesis; in this situation, the plant cannot use sunlight as an energy source for photosynthesis, resulting in a loss of capacity to perform essential functions such as nutrient uptake (Dechen and Natchtigall, 2007).

Leaf $\mathrm{S}$ concentrations had a behavior pattern similar to leaf $\mathrm{N}$ concentrations, i.e., they increased with increasing $\mathrm{N}$ levels in the solution (Figure $4 \mathrm{f}$ ). Like $\mathrm{N}$, most $\mathrm{S}$ is incorporated into proteins, with a stoichiometry between these two nutrients (Malavolta et al., 1997). The interaction between $\mathrm{N}$ and $\mathrm{S}$ seems to be related primarily to uptake and translocation, since greater $\mathrm{N}$ availability contributes to increasing $\mathrm{S}$ concentration in plant shoots (Barney Jr and Bush, 1986; Alvarez V et al., 2007), explaining the similarity of the tendencies in their concentrations observed in this study. Unlike leaf $\mathrm{N}$ and $\mathrm{S}$, leaf Ca concentrations decreased with increasing $\mathrm{N}$ application rates (Figure $4 \mathrm{~d}$ ). This 

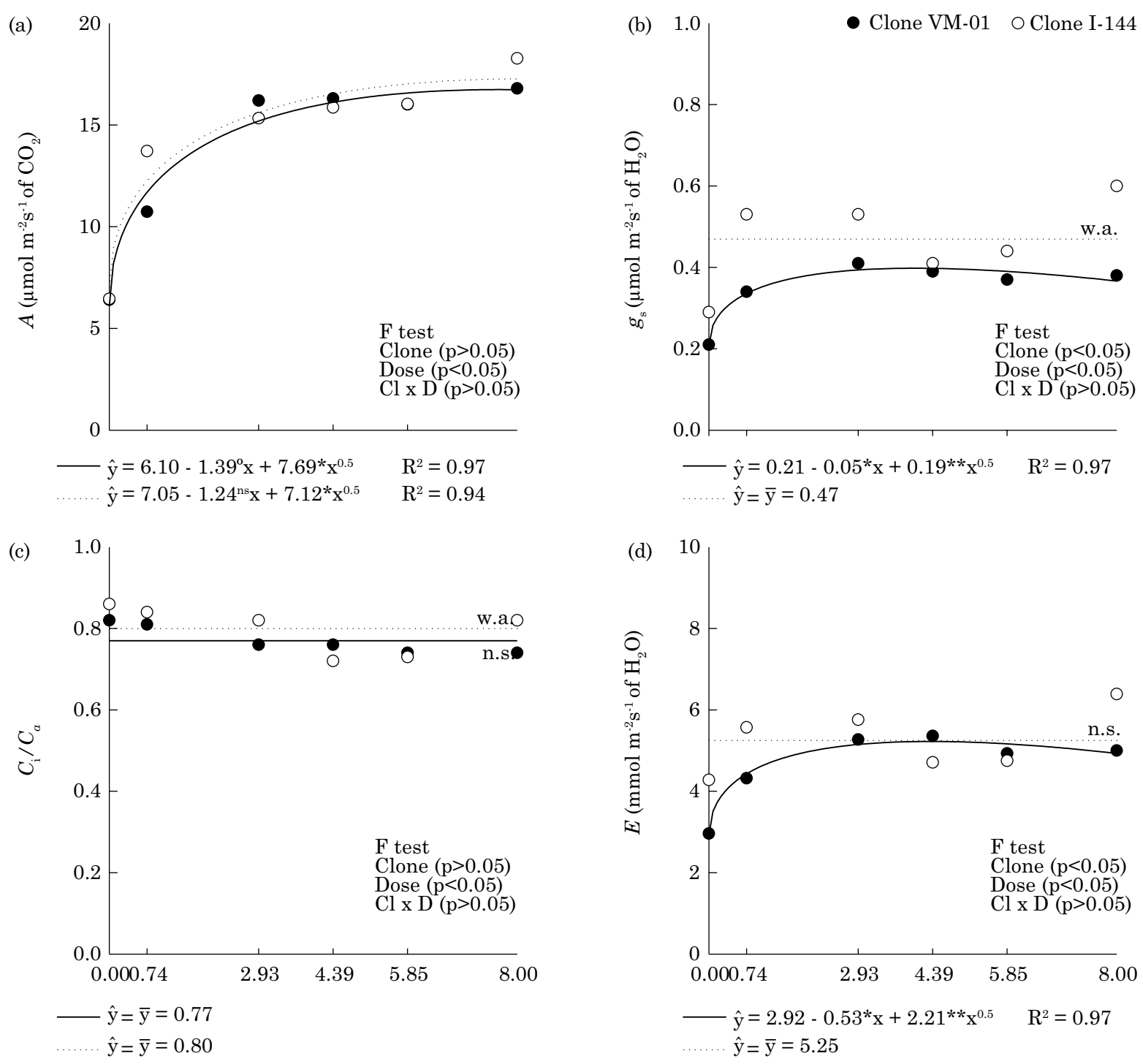

$\mathrm{N}$ application rate $\left(\mathrm{mmol} \mathrm{L}^{-1}\right.$ of $\left.\mathrm{NH}_{4} \mathrm{NO}_{3}\right)$

Figure 3. Photosynthesis - $A$ (a), stomatal conductance - $g_{\mathrm{s}}(\mathrm{b})$, leaf internal $\mathrm{CO}_{2}$ concentration $\left(C_{\mathrm{i}}\right)$ and external $\mathrm{CO}_{2}$ concentration $\left(C_{\mathrm{a}}\right)$ ratio - $C_{\mathrm{i}} / C_{\mathrm{a}}(\mathrm{c})$, and transpiration - $E(\mathrm{~d})$ of young eucalyptus clones under $\mathrm{N}$ application rates in nutrient solution. ${ }^{\mathrm{ns}}$, wa, ${ }^{\circ}, *$, and *** represent not significant, without adjustment, and significant at 10,5 , and $1 \%$ by the $F$ test $(p<0.05)$, respectively. Cl (clone) and D (application rate).

may be partially explained by preferential uptake of $\mathrm{N}$ in the form of $\mathrm{NH}_{4}^{+}$by Eucalyptus (Barros and Novais, 1996). Although the clones absorbed both mineral $\mathrm{N}$ forms $\left(\mathrm{NH}_{4}^{+}\right.$and $\mathrm{NO}_{3}^{-}$), at increasing $\mathrm{N}$ levels in the solution, the predominance of uptake of $\mathrm{NH}_{4}^{+}$increased (Ferreira, 2013), resulting in greater competition between $\mathrm{NH}_{4}^{+}$and $\mathrm{Ca}^{2+}$ ions, to the favor of $\mathrm{NH}_{4}^{+}$, which was more concentrated. Consequently, lower amounts of Ca were taken up and accumulated in the clone leaves. In common bean and corn, for example, there is a reduction in $\mathrm{Ca}$ with increasing $\mathrm{NH}_{4}^{+}$concentration (Souza and Fernandes, 2006). Vitti et al. (2006) reported that high concentrations of $\mathrm{N}$ as $\mathrm{NH}_{4}^{+}$in the plant growth medium reduce $\mathrm{Ca}$ uptake by roots. The higher leaf Ca in plants grown in the $\mathrm{N}$-free solution may also have been an effect of the Ca concentration, since the dry matter production of the plants was much lower in this situation (Figure 1).

The $\mathrm{N}$ application rates did not influence leaf $\mathrm{P}$ concentration, and the highest concentrations were found in clone VM-01 (Figure 4b). The P concentrations observed in this study were likely also the result of using a double $\mathrm{P}$ application rate, as proposed by Caldeira et al. (1994). Although the leaf K concentration was influenced by the $\mathrm{N}$ levels in solution, there were no adjustments (w.a.) to the models tested (Figure 4c). 

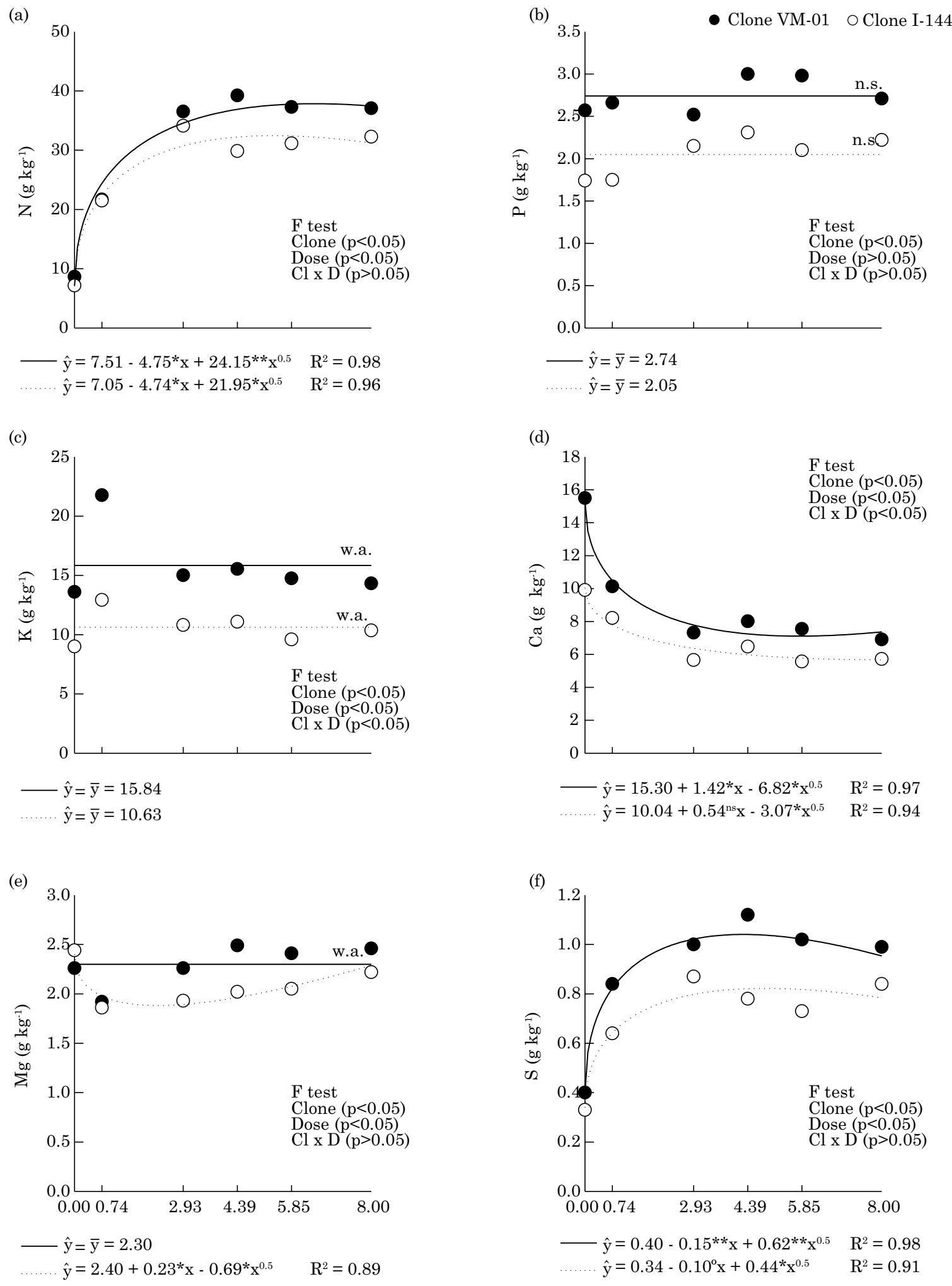

$\mathrm{N}$ application rate $\left(\mathrm{mmol} \mathrm{L}^{-1}\right.$ of $\left.\mathrm{NH}_{4} \mathrm{NO}_{3}\right)$

Figure 4. Concentration of $\mathrm{N}(\mathrm{a}), \mathrm{P}(\mathrm{b}), \mathrm{K}(\mathrm{c}), \mathrm{Ca}(\mathrm{d}), \mathrm{Mg}(\mathrm{e})$, and $\mathrm{S}$ (f) in leaves of young eucalyptus clones under $\mathrm{N}$ application rates in nutrient solution. ${ }^{\mathrm{ns}}$, wa, ${ }^{\circ}, *$, and $* *$ represent not significant, without adjustment, and significant at 10,5 , and $1 \%$ by the $F$ test $(p<0.05)$, respectively. $C l$ (clone) and D (application rate). 
(a)

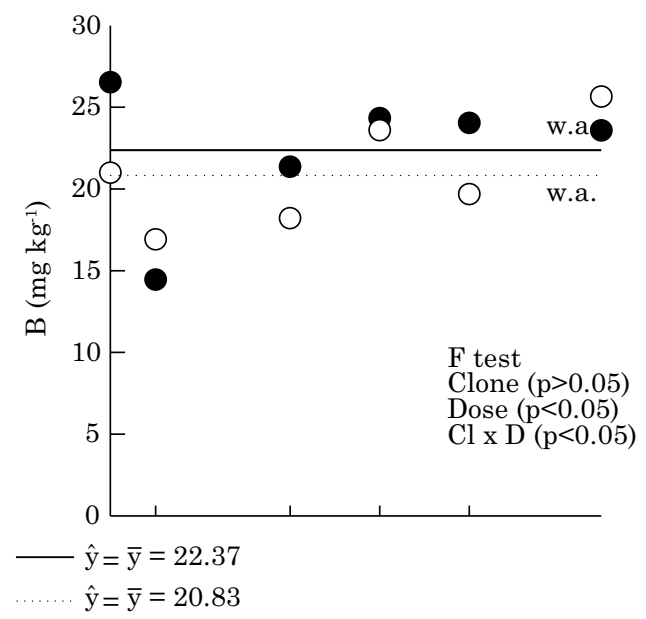

(c)

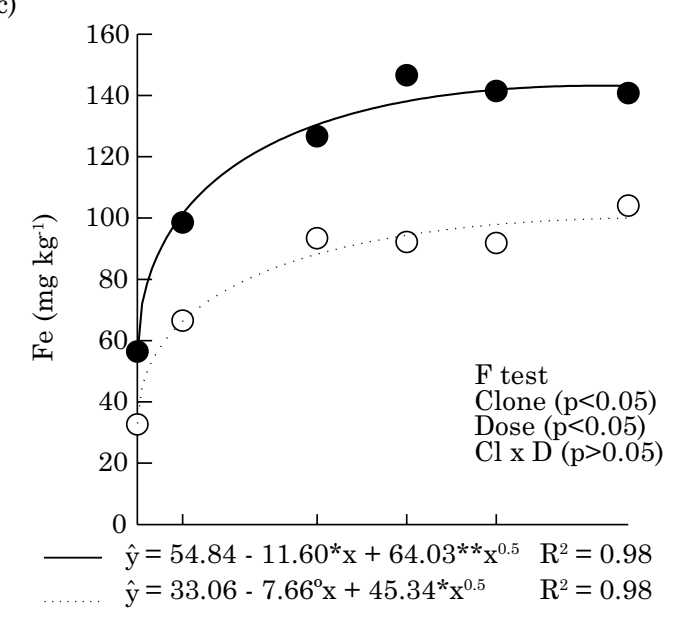

(e)

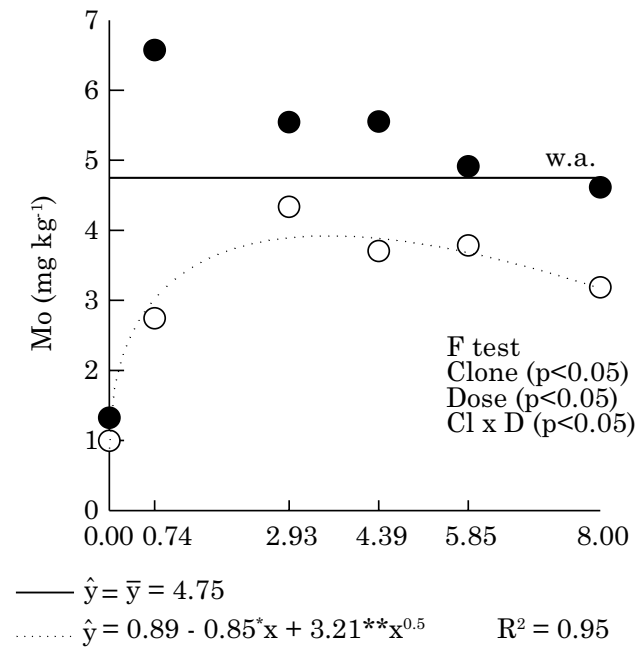

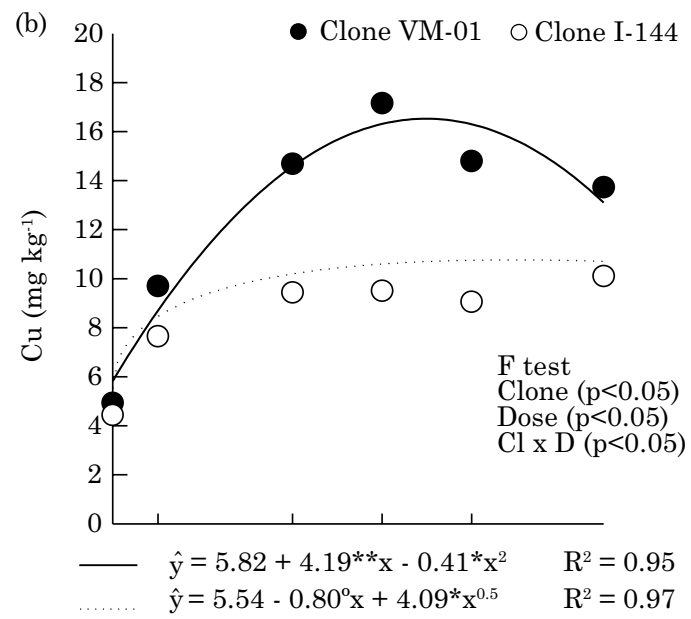

(d)
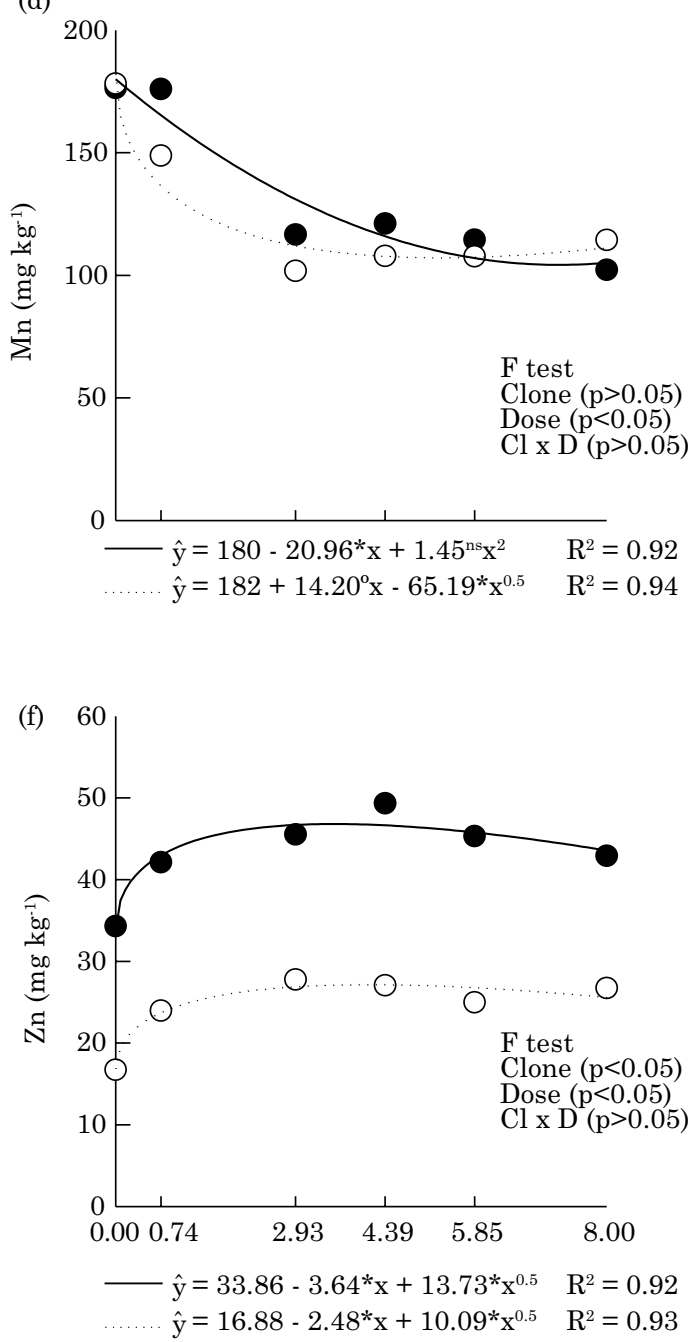

$\mathrm{N}$ application rate $\left(\mathrm{mmol} \mathrm{L}-1\right.$ of $\left.\mathrm{NH}_{4} \mathrm{NO}_{3}\right)$

Figure 5. Concentration of B (a), $\mathrm{Cu}$ (b), Fe (c), Mn (d), Mo (e), and $\mathrm{Zn}$ (f) in leaves of young eucalyptus clones under $\mathrm{N}$ application rates in nutrient solution. ${ }^{\mathrm{ns}}$, wa $,{ }^{\circ}, *$, and ** represent not significant, without adjustment, and significant at 10,5 , and $1 \%$ by the $F$ test $(p<0.05)$, respectively. Cl (clone) and $D$ (application rate). 
Potassium plays an important role in regulating the osmotic potential of plant cells (Marschner, 2012), contributing to stomatal opening and closure (Dechen and Nachtigall, 2007). Thus, the plants with the lowest $\mathrm{K}$ concentration (application rate 0 of $\mathrm{NH}_{4} \mathrm{NO}_{3}$ ) also had lower values of $A, g_{s}$, and $E$ (Figures $3 \mathrm{a}, 3 \mathrm{~b}$, and $3 d$ ), thereby contributing to lower total dry matter production (Figure 1d), since $\mathrm{K}$ deficiency does not allow the stomata to open fully or close quickly, causing limited control over water loss from plants (Dechen and Nachtigall, 2007).

A behavior without adjustment (w.a.) of the Mg concentration in VM-01 was also observed, whereas $\mathrm{Mg}$ concentration was reduced when $\mathrm{N}$ was added to the growth solution of clone I-144 (Figure 4e). However, except for $\mathrm{Mg}$ concentration in the treatment without $\mathrm{N}$, it was observed that there is an almost linear increase in $\mathrm{Mg}$ with increasing $\mathrm{N}$ application rates for both clones, following the increase in $\mathrm{N}$ concentration (Figure 4a) and $A$ (Figure $3 \mathrm{a}$ ). This is because $\mathrm{Mg}$, along with $\mathrm{N}$, plays a role as a structural component of the chlorophyll molecule and is therefore essential for photosynthesis (Marschner, 2012). For clone I-144 in the $\mathrm{N}$-free solution, there was a peak in $\mathrm{Mg}$ uptake, which fitted a square root model. In this situation, competition between $\mathrm{NH}_{4}^{+}$and $\mathrm{Mg}^{2+}$ ions in solution is rather unlikely, since there was no $\mathrm{N}$ in solution, thus favoring $\mathrm{Mg}$ uptake. Leaf $\mathrm{Mg}$ concentration may also have been favored by a concentration effect, as a result of lower shoot dry matter (Figure 1a), as observed for leaf Ca concentration (Figure 4d).

Lastly, the $\mathrm{N}$ levels in solution influenced the leaf concentration of all micronutrients (Figure 5). The leaf B concentration, with means of $22 \mathrm{mg} \mathrm{kg}^{-1}$ for clone VM-01, and $21 \mathrm{mg} \mathrm{kg}^{-1}$ for I-144, did not fit the regression models tested (Figure 5a). Nunes (2010), testing B ( $\left.15 \mu \mathrm{mol} \mathrm{L}^{-1}\right)$ in nutrient solution, close to the B concentration used in this study $\left(19 \mu \mathrm{mol} \mathrm{L}^{-1} \mathrm{~B}\right)$, obtained mean leaf concentrations of 47 and $59 \mathrm{mg} \mathrm{kg}^{-1} \mathrm{~B}$ in drought-sensitive and drought-tolerant Eucalyptus clones, respectively. Although the characteristic B deficiency symptom is necrosis of young leaves and terminal buds, a wide variety of symptoms are observed in B-deficient plants, depending on species and age (Taiz and Zeiger, 2004). However, no visual symptoms of B deficiency were observed in the plants of this study; perhaps the growing period was not long enough to allow their manifestation. There was a reduction in leaf $\mathrm{Mn}$ concentration with increased $\mathrm{N}$ application rates (quadratic and square root models), with a minimum value of $102 \mathrm{mg} \mathrm{kg}^{-1} \mathrm{Mn}$ for both clones (Figure 5d). Manganese inhibits Fe uptake and, in turn, Mn uptake is inhibited by Mg (Malavolta et al., 1997) so, in general, plants with lower leaf $\mathrm{Mn}$ concentrations also had higher $\mathrm{Mg}$ (Figure 4e) and Fe concentrations (Figure 5c).
An increase in the concentrations of the micronutrients $\mathrm{Cu}, \mathrm{Fe}, \mathrm{Mo}$, and $\mathrm{Zn}$ was observed in the leaves with application of greater $\mathrm{N}$ levels in the solution (Figures 5b, 5c, 5e, and 5f, respectively). Apart from the $\mathrm{Cu}$ (quadratic adjustment) and Mo (w.a.) concentrations in clone VM-01, the concentrations of the aforementioned nutrients in clone I-144, and of $\mathrm{Fe}$ and $\mathrm{Zn}$ in both clones, were fitted with a square root model.

Clearly, clone VM-01 had higher concentrations $(p<0.05)$ of these four micronutrients. These results indicate that clone VM-01 does not only take up more $\mathrm{N}$ but, in general, also takes up more of the other nutrients evaluated than clone I-144. Whereas the $\mathrm{Cu}$ and Mo concentrations of both clones are above the range considered optimal for normal Eucalyptus growth (Malavolta et al., 1997), the Fe and $\mathrm{Zn}$ concentrations of clone I-144 are below these ranges. One of the functions of Mo is related to nitrate reductase, which catalyzes the reduction of $\mathrm{NO}_{3}^{-}$to $\mathrm{NO}_{2}^{-}$(Marschner, 2012). Under Mo deficiency, $\mathrm{N}$ accumulates as $\mathrm{NO}_{3}^{-}$in the plant; so, the lack of Mo and of $\mathrm{N}$ has similar effects (Dechen and Nachtigall, 2007). However, in this experiment, high Mo concentrations were found in plants, corroborating the higher $\mathrm{NH}_{4}^{+}$concentrations (Ferreira, 2013). However, toxic effects of Mo were not observed in either Eucalyptus clone, because, according to Dechen and Nachtigall (2007), although the plants require small amounts of this micronutrient ( $<1.0 \mathrm{mg} \mathrm{kg}^{-1} \mathrm{Mo}$ ), large amounts of molybdate can be taken up without toxic effects. Whereas $\mathrm{P}$ stimulates Mo uptake, it can also induce Zn deficiency in plants, because it decreases $\mathrm{Zn}$ uptake at high concentrations (Malavolta et al., 1997). This may explain the very high Mo and lower leaf Zn concentrations observed in this study, since the $\mathrm{P}$ concentration in the nutrient solution had been doubled. Corroborating this fact, a mean concentration of $75 \mathrm{mg} \mathrm{kg}^{-1} \mathrm{Zn}$ was found in the shoot of $E$. maculate and $E$. urophylla seedlings even without adding $\mathrm{Zn}$ to Clark's nutrient solution (Soares et al., 2001).

\section{CONCLUSIONS}

The $\mathrm{N}$ supply was associated with better nutrition, higher photosynthetic rates, and an increase in growth and dry matter production of Eucalyptus clones.

Clone VM-01 had greater plant height, height/ collar diameter ratio, and higher leaf concentrations of all macronutrients and of $\mathrm{Cu}, \mathrm{Fe}, \mathrm{Mo}$, and $\mathrm{Zn}$, while root and total dry matter production, root/shoot ratio, collar diameter, $g_{s}$, and $E$ of clone I-144 were higher.

The Eucalyptus clones VM-01 and I-144 performed differently, and the growth of I-144, despite a lower leaf $\mathrm{N}$ concentration, was generally better than that of VM-01. 


\section{ACKNOWLEDGMENTS}

We are very grateful to the National Council of Technological and Scientific Development (CNPq) for financial support (project funding - Process N. 473245/2011-6, and Ph.D. scholarship) and Vallourec \& Mannesmann Tubes Forestry Company (V\&M Tubes) for offering the experimental areas and also for providing assistance in soil and leaf sampling.

\section{REFERENCES}

Alvarez V VH, Roscoe R, Kurihara CH, Pereira NF. Enxofre. In: Novais RF, Alvarez V VH, Barros NF, Fontes RLF, Cantarutti RB, Neves JCL, editores. Fertilidade do solo. Viçosa, MG: Sociedade Brasileira de Ciência do Solo; 2007. p.595-635.

Améziane R, Limami MA, Noctor G, Morot-Gaudry JF. Effect of nitrate concentration during growth on carbon partitioning and sink strength in chicory. J Exp Bot. 1995;46:1423-8.

Associação Brasileira de Produtores de Florestas Plantadas - Abraf. Anuário estatístico ABRAF: ano base 2011. Brasília: 2012.

Barney Jr, PE, Bush LP. Interaction of nitrate and sulfate reduction in tobacco. 1 . Influence of availability of nitrate and sulfate. J Plant Nutr. 1986;8:505-15.

Barros NF, Neves JCL, Novais RF. Mineral fertilizer recommendations for Eucalyptus plantations. In: Gonçalves JLM, Benedetti V, editors. Forest nutrition and fertilization. Piracicaba: Institute of Forestry Research; 2004. p.269-305.

Barros NF, Novais RF. Eucalyptus nutrition and fertilizer regimes in Brazil. In: Attiwill PM, Adams MA, editors. Nutrition of Eucalyptus. Melbourne: CSIRO; 1996. p.335-55.

Barros NF, Novais RF, Neves JCL. Fertilização e correção do solo para o plantio de eucalipto. In: Barros NF, Novais RF, editores. Relação solo-eucalipto. Viçosa, MG: Folha de Viçosa; 1990. p.127-86.

Bremner JM. Nitrogen-total. In: Sparks DL, editor. Methods of gril analysis. Chemical methods. Madison: Soil Science Society of America; 1996. p.1085-121.

Bungard RA, Mcneil D, Morton JD. Effects of nitrogen on the photosynthetic apparatus of Clematis vitalba growth at several irradiances. Aust J Plant Physiol. 1997;24:205-14.

Caldeira MTM, Sant'anna N, Cambraia J, Barros NF, Novais RF. Efeito da interação N x S sobre a composição das frações nitrogenada e sulfurada e sobre a atividade da redutase do nitrato em eucalipto. R Bras Fisiol Veg. 1994;61:59-65.

Chaperon H. Vegetative propagation of Eucalyptus. In: Simpósio de Melhoramento y Mejoramiento de Especies Forestales. Buenos Aires: CIEF; 1987. p.215-32.

Ciompi S, Gentile E, Guidi L, Soldatini GF. The effect of nitrogen deficiency on leaf gas exchange and chlorophyll fluorescence parameters in sun flower. Plant Sci. 1996;118:177-84.

Clark RB. Characterization of phosphatase of intact maize roots. J Agric Food Chem. 1975;23:458-60.

Cruz C, Lips SH, Martins-Loução MA. Nitrogen assimilation and transport in carob plants. In: Kylin A, editor. Proceedings of the Third International Symposium on Inorganic Nitrogen Assimilation. Tiberias, [Israel]: 1993. p.524-31.

Daley PF, Raschke K, Ball JY, Berry JA. Topography of photosynthetic activity of leaves obtained from video images of chlorophyll fluorescence. Plant Physiol. 1989;90:1233-8.

Dechen AR, Nachtigall GR. Elementos requeridos à nutrição de plantas. In: Novais RF, Alvarez V VH, Barros NF, Fontes RLF, Cantarutti RB, Neves JCL, editores. Fertilidade do solo. Viçosa, MG: Sociedade Brasileira de Ciência do Solo; 2007. p.91-132.

Ferreira EVO. Indicadores fisiológicos do status de nitrogênio em plantas de eucalipto [tese]. Viçosa, MG: Universidade Federal de Viçosa; 2013.

Field C. Allocating leaf nitrogen for the maximization of carbon gain: leaf age as a control on the allocation program. Oecologia. 1983;56:341-7.

Furlani AMC. Nutrição mineral. In: Kerbauy GB, editor. Fisiologia vegetal. Rio de Janeiro: Guanabara Koogan; 2004. p.40-75.

Furtini Neto AE. Eficiência nutricional, cinética de absorção e frações fosfatadas em Eucalyptus ssp [tese]. Viçosa, MG: Universidade Federal de Viçosa; 1994.

Furtini Neto AE, Barros NF, Godoy MF, Novais RF. Eficiência nutricional de mudas de Eucalyptus em relação a fósforo. R Árvore. 1996;20:17-28.

Garategui AL. Study of the nitrogen response of Eucalyptus dunnii Maiden for biomass production [dissertação]. Montevideo [Uruguay]: Universidad de la Republica; 2002.

Gastal F, Lemaire G. N uptake and distribution in crops: an agronomical and ecophysiological perspective. J Exp Bot. 2002;53:789-99.

Gonçalves JLM, Stape JL, Benedetti V, Fessel VAG, Gava JL. Reflexos do cultivo mínimo e intensivo do solo em sua fertilidade e na nutrição das árvores. In: Gonçalves JLM, Benedetti V, editores. Nutrição e fertilização florestal. Piracicaba: Instituto de Pesquisas Florestais; 2000. p.1-58

Hay RKM, Porter JR. The physiology of crop yield. $2^{\text {nd }}$.ed. Oxford: Blackwell; 2006.

Hirel BJ, Le Gouis NB, Gallais A. The challenge of improving nitrogen use efficiency in crop plants: towards a more central role for genetic variability and quantitative genetics within integrated approaches. J Exp Bot. 2007;58:2369-87.

Hunt ER, Weber JA, Gates DM. Effects of nitrate application on Amaranthus powelli Wats. III. Optimal allocation of leaf nitrogen for photosynthesis and stomatal conductance. Plant Physiol. 1985;79:619-24.

Jesus GL, Barros NF, Silva IR, Neves JCL, Henriques EP, Lima VC, Fernandes LV, Soares EMB. Doses e fontes de nitrogênio na produtividade do eucalipto e nas frações da matéria orgânica em solo da região do cerrado de Minas Gerais. R Bras Ci Solo. 2012;36:201-14.

Leite FP, Silva IR, Novais RF, Barros NF, Neves JCL, Villani EMA. Nutrient relations during an Eucalyptus cycle at different population densities. R Bras Ci Solo. 2011;35:949-59.

Lima AMN, Neves JCL, Silva IR, Leite FP. Cinética de absorção e eficiência nutricional de $\mathrm{K}$, Ca e $\mathrm{Mg}$ em plantas jovens de quatro clones de eucalipto. R Bras Ci Solo. 2005;29:903-9. 
Lima JD, Damatta FM, Mosquim PR. Growth attributes, xylem sap composition, and photosynthesis in common bean as affected by nitrogen and phosphorus deficiency. J Plant Nutr. 2000;23:937-47.

Locatelli M, Barros NF, Neves JCL, Novais RF. Efeito de formas de nitrogênio sobre o crescimento e composição mineral de mudas de eucalipto. Agrotrópica. 1984;8:53-69.

Malavolta E, Vitti GC, Oliveira SA. Avaliação do estado nutricional das plantas: Princípios e aplicações. $2^{\text {a }}$.ed. Piracicaba: Associação Brasileira para Pesquisa da Potassa e Fosfato; 1997.

Majerowicz N, Kerbauy GB. Effects of nitrogen forms on dry matter partitioning and nitrogen metabolism in two contrasting genotypes of Catasetum fimbriatum (Orchidaceae). Environ Exp Bot. 2002;47:249-58.

Majerowicz N, Kerbauy GB, Nievola CC, Suzuki RM. Growth and nitrogen metabolism of Catasetum fimbriatum (Orchidaceae) grown with different nitrogen sources. Environ Exp Bot. 2000;44:195-206.

Marschner H. Mineral nutrition of higher plants. London: Academic Press; 1995.

Marschner H, Kirkby EA, Cakmak I. Effect of mineral nutritional status on shoot-root partitioning of photoassimilates and cycling of mineral nutrients. J Exp Bot. 1996;47:1255-63.

Marschner P. Mineral nutrition of higher plants. London: Academic Press; 2012.

Martinez HEP, Novais RF, Sacramento LVS, Rodrigues LA. Comportamento de variedades de soja cultivadas sob diferentes níveis de fósforo: II. Translocação do fósforo absorvido e eficiência nutricional. R Bras Ci Solo. 1993;17:239-44.

Mattiello EM, Ruiz HA, Silva IR, Guerra PC, Andrade VM. Características fisiológicas e crescimento de clones de eucalipto em resposta ao boro. R Árvore. 2009;33:821-30.

Müller C, Detmann KSC, Pereira GL, Batista HCS, Figueiredo AC, Marinho AF, Barros NF. Alterações fisiológicas e de crescimento em clones de eucalipto em resposta ao déficit hídrico e suprimento de boro. In: FERTBIO [CD-ROM]. Maceió: Universidade Federal de Alagoas; 2012.

Neves JCL. Produção e partição de biomassa, aspectos nutricionais e híbridos em plantios clonais de eucalipto na região litorânea do Espírito Santo [tese]. Campos dos Goytacazes: Universidade Estadual do Norte Fluminense; 2000.

Niinemmets U, Cescatti A, Rodeghiero M. Complex adjustments of photosynthetic potentials and internal diffusion conductance to current and previous light availability leaf age in Mediterranean evergreen species Quercus ilex. Plant Cell Environ. 2006;29:1159-78.

Nunes FN. Crescimento e expressão gênica em clones de eucalipto influenciados pelo boro e déficit hídrico [tese]. Viçosa, MG: Universidade Federal de Viçosa; 2010.

Onoda Y, Hokosaka K, Hirose T. Allocation of nitrogen to cell walls decreases photosynthetic nitrogen-use efficiency. Funct Ecol. 2004;18:419-25.

Pinto SIC. Cinética de absorção conjunta de fósforo, potássio, cálcio e magnésio e eficiência nutricional de macronutrientes de clones de eucalipto [tese]. Lavras: Universidade Federal de Lavras; 2009.

Pinto SIC, Furtini Neto AE, Neves, JCL, Faquin V, Moretti BS. Eficiência nutricional de clones de eucalipto na fase de mudas cultivados em solução nutritiva. R Bras Ci Solo. 2011;35:523-33.

Pulito AP. Resposta à fertilização nitrogenada e estoque de nitrogênio biodisponível em solos usados para plantações de Eucalyptus [dissertação]. Piracicaba: Escola Superior de Agricultura Luiz de Queiroz; 2009.

Raven PH, Evert RF, Eichhom SE. Biology of plants. New York: Worth Publishers; 1986.

Reddy AR, Chaitanya KV, Vivekanandan M. Drought-induced responses of photosynthesis and antioxidant metabolism in higher plants. J Plant Physiol. 2004;161:1189-202.

Santana RC, Barros NF, Neves JCL. Eficiência de utilização de nutrientes e sustentabilidade da produção em procedências de Eucalyptus grandis e Eucalyptus saligna em sítios florestais do Estado de São Paulo. R Árvore. 2002;26:447-57.

SAS Institute Inc. SAS/STAT ${ }^{\circledR}$ 9.1 User's guide. Cary, NC: 2004.

Silveira RLVA, Gonçalves AN, Silveira RI, Branco EF. Levantamento nutricional de florestas de Eucalyptus grandis na região de Itatinga-SP: I. Macronutrientes e II Micronutrientes. In: Congresso Brasileiro de Ciência do Solo, 1995, Viçosa. Anais... Viçosa, MG: Sociedade Brasileira de Ciência do Solo; 1995. p.896-901.

Smethurst PJ, Holza G, Moronia M, Baillie C. Nitrogen management in Eucalyptus nitens plantations. For Ecol Manage. 2004;193:63-80.

Soares CRFS, Grazziotti PH, Siqueira JO, Carvalho JG, Moreira FMS. Toxidez de zinco no crescimento e nutrição de Eucalyptus maculata e Eucalyptus urophylla em solução nutritiva. Pesq Agropec Bras. 2001:36:339-48.

Sociedade Brasileira de Silvicultura - SBS. Facts and numbers of forestry in Brazil. São Paulo [Brasil]: 2006.

Souza SR, Fernandes MS. Nitrogênio. In: Fernandes MS, editor. Nutrição mineral de plantas. Viçosa, MG: Sociedade Brasileira de Ciência do Solo; 2006. p.215-52.

Stape JL, Benedetti V. Decréscimo da produtividade e resposta da brotação de Eucalyptus grandis à fertilização com macronutrientes em areia quartzosa no Estado de São Paulo-Brasil. In: Anais Iufro Conference on Silviculture and Improvement of Eucalypts, 1997; Salvador, [Br]. Salvador, [Br]: Embrapa; 1997. p.112-7.

Taiz L, Zeiger E. Fisiologia vegetal. $3^{\mathrm{a}}$.ed. Porto Alegre: Artmed; 2004.

Turnbull TL, Kelly N, Adams MA, Warren CR. Within-canopy nitrogen and photosynthetic gradients are unaffected by soil fertility in field-grown Eucalyptus globules. Tree Physiol. 2007;27:1607-17.

Vitti GC, Lima E, Cicarone F. Cálcio, magnésio e enxofre. In: Fernandes MS, editor. Nutrição mineral de plantas. Viçosa, MG: Sociedade Brasileira de Ciência do Solo, 2006. p.299-329.

Wadt PGS, Novais RF, Alvarez V VH, Barros NF, Dias LE. Variações no estado nutricional de eucaliptos por influência do material genético e da idade da árvore. Pesq Agropec Bras. 1999;34:1797-803.

Warren CR, Bleby T, Adams MA. Changes in gas exchange versus leaf solutes as a means to cope with summer drought in Eucalyptus marginata. Oecologia. 2007;154:1-10. 